\title{
MOTIVATIONS AND RESOURCES OF SMALL-SCALE FARMERS FOR STAYING IN THEIR VILLAGE IN NORTHEAST THAILAND
}

\author{
Masatoshi Uehara
}

Keio Research Institute at SFC, 5322 Endo, Fujisawa, Kanagawa, 252-0882, Japan.

E-mail: ultimasa@gmail.com

Citation: Uehara, M., 2019. Reasons for Staying on: Motivation and Resources of Small-scale Farmers in Rural Northeast Thailand. J. Asian Rur. Stud. 3(1): 35-47

\begin{abstract}
This study aims to examine one simple question: Why do some small-scale farmers in rural, northeast Thailand keep staying on in their villages despite the fact that they could earn a much higher income if they worked in urban areas? To answer this question, this study which is based on first-hand observations from nine years of intensive fieldwork in rural, northeast Thailand provides a detailed description of the small-scale farmers' resources that enable them to sustain a living and also provides them motivations to stay in their village. The decision to stay on in the village and forgo the option to move out in pursuit of a higher income may seem irrational in the opinion of economists. However, the author, by employing the "capability approach" argument by A. Sen, argues that their behaviour could be understood as efforts of pursuing "lives worth living" (as expressed in his later work as an architect of the UN's "human security" program) and not solely profit maximisation. Their efforts include establishing "community groups" and practising "sustainable agriculture" including "organic farming" and "integrated farming". These activities are well-suited to their natural environments and economic conditions and, at the same time, give them autonomy in their villages.
\end{abstract}

Keywords: Motivation; Small Farmers; Stay in Village; Agrarian Transformation; Rural Thailand

\section{Introduction}

Northeast Thailand, or "Isan", has been perceived as the "poorest" region of the country. Despite the rapid national economic growth after the late 1980s, there has been a significant income gap between rural and urban areas as evidenced by the income disparity between the Northeast and Bangkok. According to NESDB (Office of the National Economic and Social Development Board), the per capita GDP of northeast Thailand is only $\mathbf{B} 74,532$ (Thai baht) which is approximately $\$ 2,400$ (US dollars). On the other hand, the per capita GDP of Bangkok is ${ }_{B} 466,844$ (approximately $\$ 15,000$ ) (NESDB, 2013). Thus, the per capita GDP of Bangkok is six times larger than that of more rural Northeast.

Of course, the situation surrounding the rural communities of northeast Thailand has changed rapidly, and some recent studies point out that northeast Thailand is no longer as poor as it used to be (Rambo, 2017). The poverty rate has been declining, and income levels have been increasing, especially since the late 1980s. However, we should keep 
in mind that economic inequality between rural and urban areas, and within some rural areas, has been expanding at the same time.

One reason for the low-income level of the Northeast could be the severe environmental conditions unfit for agriculture. Seventy per cent of the population in the Northeast is living in rural areas, and the vast majority of them are engaged in rain-fed, rice farming. Fifty per cent of the farmers are defined as small-scale farmers, and they are growing sticky rice called "khao nyao" mainly for self-consumption. However, environmental conditions of the region are not optimal for rice farming. The predominance of sandy, infertile soils is unfavourable for agriculture. The rainfall is unstable, and the region is frequently affected by severe droughts in the dry season. Irrigation systems have not been fully developed in northeast Thailand. It is reported that the irrigable area is at most 10 to $15 \%$ of the entire paddy fields of the region (Watanabe, 2017). Therefore, it is challenging for farmers to have access to agricultural water, especially in the dry season. According to NSO (National Statistical Office of Thailand), farmers of northeast Thailand are cultivating 36,523,279 rai (approximately $5,800,000$ hectares) for rice production in the rainy season.

On the other hand, they are cultivating only 2,620,547 rai (approximately 480,000 hectares) in the dry season. Farmers of the Northeast can only cultivate a very limited portion of the paddy fields, about $7 \%$ of the potential harvest area, in the dry season. This means that most farmers of the Northeast can grow only one crop a year. In contrast, farmers in Bangkok and the surrounding areas can cultivate $96 \%$ of the paddy fields even in the dry season. They can grow two or more crops in a year. Furthermore, yield per rai in the Northeast is only $361 \mathrm{~kg}$, whereas yield per rai in Bangkok and the surrounding areas can reach up to $744 \mathrm{~kg}$ (NSO 2013). These figures illustrate why limited access to irrigated water restricts rain-fed rice production in northeast Thailand.

Table 1. Rice Cultivation in the Rainy Season and Dry Season (2012)

\begin{tabular}{|l|c|c|c|c|}
\hline & \multicolumn{2}{|c|}{$\begin{array}{c}\text { Rice Cultivation } \\
\text { in the Rainy Season }\end{array}$} & \multicolumn{2}{c|}{$\begin{array}{c}\text { Rice Cultivation } \\
\text { in the Dry Season }\end{array}$} \\
\hline & $\begin{array}{c}\text { Harvested area } \\
(\mathrm{rai})\end{array}$ & $\begin{array}{c}\text { Yield per rai } \\
(\mathrm{kg})\end{array}$ & $\begin{array}{c}\text { Harvested area } \\
(\mathrm{rai})\end{array}$ & $\begin{array}{c}\text { Yield per rai } \\
(\mathrm{kg})\end{array}$ \\
\hline Whole Kingdom & $61,369,270$ & 457 & $15,278,645$ & 669 \\
\hline Bangkok and Vicinity & $1,024,588$ & 744 & 987,298 & 759 \\
\hline Northeastern Region & $36,523,279$ & 361 & $2,620,547$ & 559 \\
\hline Khon Kaen Province & $2,332,375$ & 326 & 274,628 & 580 \\
\hline
\end{tabular}

Source: NSO, 2013.

The income level of the Northeast is very low, and agricultural productivity is also low. Under such conditions, the farmers in the Northeast have been increasingly relying on cash income since the 1960s when the Thai government adopted programs encouraging modern agricultural development.

The Thai government promoted the growing of cash crops such as cassava, sugarcane, and kenaf based on the First National Economic Development Plan (19611966). Since then, farmers started to purchase and use high-yield crop varieties, chemical fertilisers, pesticides, and machines to increase productivity. According to NSO (2003), 87.4\% of farmers used chemical fertilisers, and $44.6 \%$ used pesticides in 
2003. Since the late 1980 s, the market economy has penetrated deeply into rural communities in line with rapid, national economic growth. Conventional subsistence agriculture was transformed into market-oriented agriculture. Labour exchange customs called "long khek" had mostly disappeared by that time. Today, people in rural areas purchase commodities on a daily basis. Many young people are using smartphones even in rural areas. Although cash income is becoming gradually higher, expenditures have become higher at the same time. The farmers need more cash income for living.

However, agriculture cannot provide them with enough profits to give them an adequate cash income. According to NSO (2012), only 18.3\% of household income was from agriculture in rural areas of the Northeast in 2011. The vast majority of household income is from non-agriculture activities. As Takeuchi (2014) indicated that rural industry has developed rapidly and created rural jobs. In suburban areas, most people are engaged in both farming and non-farming activities. On the other hand, in remote areas where people cannot find non-farming employment, working in another location as a migrant might be the sole option to generate cash income, especially during the agricultural off-season.

Following is an example to illustrate the issue of this paper. "NP village" is a rural village in northeast Thailand where research for this paper was conducted. NP village is located in the Phon District (Amphoe Phol), more than $90 \mathrm{~km}$ from the city of Khon Kaen (thesaban Khonkaen). The population of NP village is 645 . More than $90 \%$ of the households are engaged in rain-fed rice farming. The average farmland size is $13 \mathrm{rai}$ (2.08 hectares), and the average annual household income was only $\$ 30,000$ (\$960) in 2011. There are no irrigation systems around the village. Farmers have to rely solely on rainwater. However, the village is often affected by severe droughts. It is challenging for farmers to have access to agricultural water on a consistent basis. A rural industry has not developed yet around the village. Therefore, to earn cash income during the dry season, the farmers need to migrate to the urban industrial sectors or other informal, jobproviding sectors. Every year, about 70 villagers go to Bangkok as migrant workers. If they stayed on in the village, they could earn only $\mathrm{B} 50$ to $\mathrm{B} 150$ (\$1.60 to $\$ 4.80)$ a day, even in the rainy season. However, if they move to urban areas, they could earn as much as $\$ 300$ (\$9.60) a day on a regular basis. Most migrant workers, however, are employed in the informal sectors as construction workers or taxi drivers, so their wages are even higher. Moreover, it is not difficult to move to Bangkok from the village. They can make use of public transportation at a low cost. It only costs about $\mathrm{B} 300(\$ 9.60)$ to take a bus to Bangkok. It could be an economically "rational choice" for them to migrate and seek a higher income in the agricultural off-season. Nonetheless, some villagers stay on in the village. The results of interviewing 46 households in NP village showed that 26 out of the 46 households would not leave the village even in the dry season. If they are over 50 years old, their situation is understandable. It is getting more difficult for an older people to get a job in the urban areas. According to NSO (2007), migrants over age 50 account for just $5.0 \%$ of all migrants from northeast Thailand. However, there are some villagers in their 20 s or 30 s staying on in the village. So, the research question is: "Why do they keep staying on in the village?" 


\section{Research Question: Motivations and Resources for Staying in the Villages}

The situation observed in NP village seems paradoxical. Agricultural productivity is restricted by the unfavourable environmental conditions. The village often suffers from severe droughts even in the rainy season. It is almost impossible to get access to agricultural water in the dry season. They do need to supplement their farming income with a cash income to live. However, there is almost no chance to find non-farming employment around the village because a rural industry has not developed yet. The villagers could find many more chances to get better jobs with higher wages in urban areas. However, some villagers are staying on in the village even in the agricultural offseason.

Why do some villagers keep staying on in the village despite the fact that they could earn a much higher income if they worked in urban areas? What could be the "motivations" and "resources" that entice and enable them to stay?

\section{Theoretical Framework: Capability Approach}

To explore their motivations and resources, the perspective of "capability approach" offered by A. Sen may be helpful. This approach pays close attention to individuals' abilities to convert given resources into something valuable for them. Then, valuable "beings and doings" are called "functioning". By employing this perspective, we can evaluate human "well-being" focusing not only on per capita GDP or "how much money they have", but also on their abilities or "what they could be and do", and "what they have reason to value" (Sen, 1999). If we evaluate "well-being" by referring to per capita GDP only, the decision to stay on in the village and forgo the option to move out seems economically irrational. However, cash income itself is just a means to improve "well-being". If we evaluate "well-being" by looking at their "functionings"-what they could do and be - their behaviours can be understood in different ways. There is a possibility that by staying on, they are pursuing something other than gaining a higher income, and instead, they are trying to avoid risks.

During field research in rural areas of northeast Thailand, farmers were observed implementing sustainable agriculture and staying on in their villages. For instance, 34 out of 46 households were implementing sustainable agriculture in NP village. Sustainable agriculture there is identified as a certain set of farming methods. There are five varieties of these methods: "organic farming", "integrated farming", "natural farming", "agro-forestry", and "New Theory farming". This paper explores the farmers' motivations and resources for staying on in relation to sustainable agriculture practices. This paper concludes that, through practising sustainable agriculture, these farmers are trying to procure resources to pursue "lives worth living" under their restricted socioeconomic conditions.

\section{Literature Review}

\subsection{Sustainable Agriculture in Development Plans}

Since the adoption of the Eighth National Economic and Social Development Plan (1997-2001), sustainable agriculture has been promoted by the Thai government as a practice of a larger "sufficiency economy" proposed by the former king, His Majesty 
the King Bhumibol Adulyadej. The origin of sustainable agriculture in Thailand started in the 1980s as an alternative rural-development approach for those who were resisting the mainstream modern agricultural development.

As mentioned above, since the 1960s, the government adopted modern agricultural development and encouraged the production of cash crops with the intensive use of agricultural chemicals. Through the expansion of the market economy, the income levels of rural communities have gradually increased. However, the negative impacts of the modern agricultural development are becoming more apparent. This method has caused serious problems including small-scale farmers' economic insecurity, chemical pollution, and environmental degradation. It has been reported that 38,223 or more people were injured as a result of the intensive chemical use between 1989 and 1998 (NESDB, 2004).

In the 1980s, some Buddhist monks, practical farmers, and NGOs started to practise sustainable agriculture to overcome those problems. Then, after 1997, the year of the Asian financial crisis, sustainable agriculture was integrated into the official governmental development policy. The Thai government is expecting that sustainable agriculture could absorb more labour force and play an essential role as a "social safety net" in rural areas.

According to the Eighth National Economic and Social Development Plan, sustainable agriculture includes five different types of farming methods mentioned above (NESDB, 1997). In particular, organic farming, integrated farming, and New Theory farming are prevalent in the Northeast.

Organic farming is an alternative farming method. It limits the use of agricultural chemicals (chemical fertilisers, herbicides, and pesticides) and promotes the use of less harmful, organic fertilisers for food and environmental safety.

Integrated farming is a farming method which emphasises agricultural diversification. It requires the building of farm ponds and the planting of two or more different kinds of crops in the same field. This farming method is called "rai na suan phasom" or "kaset phasom phasan". Practices of this farming method are widely observed in the Northeast because it can mitigate the risk of droughts. Farmers can make use of the farm ponds as water sources in the dry season. Through practising integrated farming, farmers are trying to reduce the use of agricultural chemicals and produce various kinds of crops all year round.

New Theory farming is a farming method which could also apply to small-scale farmers in the Northeast. Generally, farmers in the Northeast have limited farmland and water resources. To pursue self-sufficiency, New Theory farming suggests they divide the limited farmland into four parts: $30 \%$ for ponds, $30 \%$ for vegetables, $30 \%$ for rice, and the remaining $10 \%$ for other uses including raising livestock and housing. New Theory farming is similar to integrated farming because both farming methods require growing various kinds of crops to better utilise the limited farmland. The concept of New Theory farming was suggested by the former king in 1993. For most farmers in Thailand, New Theory farming is an ideal model which should be their goal. However, it is difficult to practice in reality.

We need to keep in mind that implementing sustainable agriculture does not mean going back to the "traditional way" of rural livelihood. Practising sustainable agriculture 
does not mean giving up the generation of "profits". Rather, it focuses on and prioritises the "benefits" of small-scale farming (Thanwa, 2001).

\subsection{Agrarian Transformation in Northeast Thailand}

Consequently, the impacts of the sustainable agriculture policy remain very limited. Since 1997, when there was the Asian financial crisis, the Thai government has been promoting sustainable agriculture in its national development plan. At first, the Thai government planned to convert $20 \%$ of the national arable land into sustainable agriculture by 1999 . However, the project covered only $3 \%$ of the entire arable land (NESDB, 2004). Atsushi Kitahara (2002) pointed out the limitations of sustainable agriculture as it is most appropriately applicable to large-scale farmers. Ironically, it is difficult for small-scale farmers to implement sustainable agriculture because of their limited resources.

Recent empirical studies criticise the conventional model provided by the "community culture school" as they do not reflect the changing reality especially after the end of the 1980s [Rambo, 2017). Recent studies are paying closer attention to rapid changes in the rural life of northeast Thailand using the term "agrarian transformation". Under the pressure of commercialisation, people have been relying more on nonfarming activities. It may be important to update the conventional perceptions of the Northeast held by academics, policymakers, members of the mass media, and the urban public. There is a certain bias in the tendency of a preference for "agrarian transformation".

Then, what could be the significance to examine practices of sustainable agriculture? The tendency, which discards sustainable agriculture as obsolete, might be an underestimation. Even though the modernised way of rural livelihood may be more rational, there are still a certain number of people who do not choose to live in such a way.

\section{Field Research in Three Villages}

For the stated purpose above, research was conducted in three villages of Khon Kaen Province which is located in the middle of northeast Thailand from August 2004 to March 2012. Khon Kaen Province is about $440 \mathrm{~km}$ from Bangkok. In the 1960s, the Thai government started to concentrate on the development of Khon Kaen Province as a model for all provinces of the Northeast. Khon Kaen University, the first university in northeast Thailand, was established at that time. Since then, infrastructures including railways and highways have been developed at a rapid pace. A major highway known as "Friendship Road" or "thanon mitraphap" now connects central and northeast Thailand. Today, the city of Khon Kaen is one of the biggest cities in northeast Thailand. There are many stores, companies, and factories, and even a large, modernised shopping mall which opened in 2010. A growing population of middle-income-class people is enjoying various consumption activities. Their situations differ significantly from the situations in rural areas. The features of the province are suitable for studying changing, rural livelihoods including the practices of sustainable agriculture. 
Upon the recommendation of the Department of Agricultural Extension and faculty at Khon Kaen University, three villages were selected for the field research. In every village, some of the villagers are migrant workers and practice sustainable agriculture. A village named "BC" in the Mueang District (Amphoe Mueang) is just $15 \mathrm{~km}$ from the city of Khon Kaen. For contrast, the other two villages named "NP" and "NW" are in the Phon District (Amphoe Phol) which is located in a more remote area. As for NP village, the village is located approximately $95 \mathrm{~km}$ south of the city of Khon Kaen.

Interviews were conducted in 27 households 31 times in $\mathrm{BC}$ village, in 46 households 60 times in NP village, and in 100 households 120 times in NW village, respectively.

Table 2. Socio-Economic Profiles of the Three Villages (2011)

\begin{tabular}{|c|c|c|c|}
\hline Village & BC & NP & NW \\
\hline Population & $\begin{array}{l}808 \\
(215 \text { households) }\end{array}$ & $\begin{array}{l}640 \\
(119 \\
\text { households) }\end{array}$ & $\begin{array}{l}559 \\
\text { (120 households) }\end{array}$ \\
\hline Distance from $\mathrm{KK}$ & $15 \mathrm{~km}$ & $90 \mathrm{~km}$ & $75 \mathrm{~km}$ \\
\hline Av. Farmland size & $10 \mathrm{rai}$ & $15 \mathrm{rai}$ & $13 \mathrm{rai}$ \\
\hline Av. Annual income & B 40,000 & B30,000 & B30,000 \\
\hline Rice yield per rai & $800 \mathrm{~kg}$ & $400 \mathrm{~kg}$ & $430 \mathrm{~kg}$ \\
\hline Major crops & $\begin{array}{l}\text { rice, chili, eggplant, } \\
\text { Chinese cabbage, shallot }\end{array}$ & rice, sugarcane & $\begin{array}{l}\text { rice, sugarcane, } \\
\text { cassava, mango }\end{array}$ \\
\hline Irrigation systems & irrigation canals & none & none \\
\hline Migrant workers & 40 villagers & 70 villagers & $\mathrm{n} / \mathrm{a}$ \\
\hline
\end{tabular}

\section{Case Analysis}

\subsection{The Case of a Village in a Suburban Area}

$\mathrm{BC}$ village is a typical case of recent "agrarian transformation". BC village is located in the suburban area of the city of Khon Kaen. It takes only 10 minutes by car or motorbike from the village to the city centre. Many villagers commute daily to the city. Some villagers work for private companies in the downtown area of Khon Kaen and factories near the village. The vast majority of household income is obtained from nonagricultural employment. Many households are engaged in both farming and nonfarming activities. At this point, $\mathrm{BC}$ village has been reaping the benefits of rural industrialisation. The village differs from the other two villages where no one commutes to the city of Khon Kaen.

Among the three villages, the income level of $\mathrm{BC}$ village is the highest. The average annual household income of $\mathrm{BC}$ village was estimated to be about $\$ 40,000(\$ 1,300)$. One reason for this relatively high income is the convenient access to the produce markets in the city of Khon Kaen. BC village is much closer to the city of Khon Kaen than the other two villages. Some villagers commute to the city or go to sell vegetables and fruits at the open market in the city. Agriculture in $\mathrm{BC}$ village is market-oriented, not subsistence-oriented anymore. The villagers of $\mathrm{BC}$ village have been adapting to the 
changing economic conditions surrounding the village and have been reaping benefits from the rapid development of the city of Khon Kaen.

For instance, Mrs Phaibun, a 29-year-old woman from the village, is working for an insurance company in the city of Khon Kaen. She is commuting from BC village to the city by motorbike. Her monthly salary is $\mathrm{B} 8,000(\$ 240)$. She earns nearly $\mathrm{B} 100,000$ $(\$ 3,000)$ in a year on a regular basis. She lives with her parents and supports them. She can access social security, and her family enjoys a stable life.

Moreover, high agricultural productivity could be another reason for the higher income. The Nam Phong River flows around BC village, and there are irrigation canals. Villagers of $\mathrm{BC}$ village can access irrigated water, and they can grow rice and other crops even in the dry season. Rice productivity is quite high, about $800 \mathrm{~kg}$ per rai. The average rice productivity of the Northeast is only $326 \mathrm{~kg}$ per rai.

Mr Wattana is a farmer of BC village. When first interviewed in 2004, he was 46 years old. He lives with his four family members: his wife, two sons, and a granddaughter. He was growing rice and various kinds of vegetables such as Chinese cabbage, shallots, and onions mainly for sale in the local market. By using the irrigated water flowing in the canals, he can grow crops throughout the year. Sometimes, he goes to the markets in the city of Khon Kaen and sells his produce. To decide what kinds of crops he plants and when he sells them, he frequently goes to the district office and researches the crop price changes so he can obtain the best prices for his produce. "Market information is very helpful to sell my products profitably", he explained.

Unlike other villages in northeast Thailand, drought is not a constant problem in BC village. For the villagers of $\mathrm{BC}$ village, alcohol and drug abuse among youth are recognised as more serious problems. Many villagers are engaged in non-farming employment and highly market-oriented agriculture.

Community groups are promoting sustainable agriculture also in $\mathrm{BC}$ village. However, compared with the other two villages, the activities of such groups are very limited. Because most villagers are engaged in profit-oriented agriculture using water stably supplied from irrigation canals, they do not recognise the necessity to introduce sustainable agriculture. At this point, cases from the latter two villages show a clear contrast.

\subsection{The Case of Village in Remote Area}

$\mathrm{NP}$ village and NW village share some similarities. Both villages are located in remote areas on the south border of Khon Kaen Province. Villagers of those villages cannot access irrigated water, and it is almost impossible to grow rice in the dry season. Rice productivity is much lower than that of $\mathrm{BC}$ village.

Some research indicates that small-scale farmers cannot reap the benefits from modern agriculture methods (CIIFAD, 1999) To achieve higher productivity, modern agriculture requires specific conditions such as a dependable water supply, fertile soil, chemical inputs, high-yielding crop varieties, capital to purchase these items, sufficient land size, and other institutional environments. However, it is challenging to satisfy these conditions for small-scale farmers. Thus, for the small-scale farmers, an alternative agricultural approach would be a more rational choice.

As mentioned before, both NP and NW villages are located quite far from the city of Khon Kaen, and it is almost impossible for villagers to commute to the city. Migrant 
work could be a significant income source, especially in the dry season. Annual household income is relatively low, only $\$ 30,000$ compared with $\$ 40,000$ of $\mathrm{BC}$ village.

It was observed that there, some villagers keep staying on in the village even in the dry season. In NP village, the farthest from the city of Khon Kaen of the three villages, 26 out of 46 households are not relying on migrant work and staying on in the village. How could they sustain their lives in these remote, rural villages?

Mr Suchart is a small-scale farmer of NP village. He was 37 years old when first interviewed in 2009. His farmland size is only seven rai (1.12 hectares). He has been practising sustainable agriculture since 2002 . He built a fishpond in his field and planted various kinds of crops around the fishpond. He can grow sticky rice, vegetables, and fruits in his limited field. Even in the dry season, he can grow some corn and beans by using water from the pond. By doing this, he can procure resources for living by practising sustainable agriculture all year round. His annual income is approximately B30,000, not very high, but adequate because he helps maintain his livelihood with sustainable agriculture. He can live without going engaging in migrant work. Before he introduced sustainable agriculture, he cultivated rice only, and he had to go to Bangkok as a migrant worker just like the other villagers. But after practicing sustainable agriculture he did not go to Bangkok anymore. "It was really uncomfortable to work in Bangkok", he said. He complained he could not get used to the polluted air in Bangkok. "Now I have work every day all year round in the village", he added. "I am very happy to stay home with my family."

In these villages, some small-scale farmers are implementing sustainable agriculture and trying to procure resources to sustain them throughout the year. In terms of an income generation strategy, impacts of sustainable agriculture are limited. However, sustainable agriculture can provide an alternative for rural livelihoods.

\subsection{Community Groups}

Some community groups can reduce the costs of introducing sustainable agriculture by providing information and resources to the members of their communities. In the three villages selected for the field research, some community groups have had an important role in promoting sustainable agriculture. There are many hurdles to overcome to help change the farming methods from modern agriculture to organic farming or integrated farming. As NESDB points out, farmers need to study the knowhow of sustainable agriculture including the appropriate use of organic fertilisers (NESDB, 2004). Moreover, if they introduce integrated farming, they need to build farm ponds in their fields. Usually, that in itself costs more than $\mathrm{B} 10,000$. As mentioned above, it is difficult to introduce sustainable agriculture, especially for small-scale farmers. However, some community groups can function as a revolving fund, and members can borrow money for agricultural investments. 
Table 3. Community Groups in Three Villages

\begin{tabular}{|l|l|l|}
\hline \multicolumn{1}{|c|}{ BC village } & \multicolumn{1}{c|}{ NP village } & \multicolumn{1}{c|}{ NW village } \\
\hline Organic agriculture & "Isan Wisdom" & Community market \\
Organic vegetable & Livestock & Organic herbs \\
Fishery & Housewife & Organic rice \\
Housewife & Silk weaving & Organic vegetables \\
Watercourse & Mulberry & Livestock \\
Village fund & Village fund & Housewife \\
Health volunteer & Health volunteer & Saving union \\
& & Village fund \\
& & Health volunteer \\
& & \\
\hline
\end{tabular}

For instance, "Isan Wisdom" of NP village is a community group promoting sustainable agriculture. This group was established in 1994 by nine practical farmers of NP village. The group is providing skills and knowledge regarding sustainable agriculture. Often, the group invites experts from Khon Kaen University and practical farmers from other villages. The number of the members has risen from nine people in 1994 to 109 people in 2011. There are 119 households in NP village. In principle, one person from each household can participate in the group. Thus, most households of the village are participating in the group.

The group is promoting the "One-Rai Project" in NP village. New Theory farming promoted by the Thai government is targeting small-scale farmers in northeast Thailand and assuming $15 \mathrm{rai}$ (2.4 hectares) of farmland. However, the average farmland size of NP villagers is only 13 rai (2.08 hectares). Many farmers throughout the Northwest do not have 15 rai. So, the head of the "Isan Wisdom" group designed a new farming method for small-scale farmers in the village. Unlike New Theory farming, the One-Rai Project requires only one rai of farmland. Within that limited field, it requires the building of a fishpond and the planting of various fruits trees and vegetable around the pond. In the dry season, farmers can make use of rainwater collected in the pond and grow vegetables and fruits. Although this farming method does not provide much surplus, at least it can provide resources for "self-sufficiency".

"The One-Rai Project can sustain four family members all-year round," the head of the group explained. Furthermore, this farming method applies to small-scale farmers who do not have enough farmland to implement New Theory farming. The One-Rai Project is implemented by 22 farmers in NP village including Mr Suchart. As Kitahara (2002) pointed out, generally, it is difficult for small-scale farmers to implement sustainable agriculture. However, some community groups could reduce the costs of implementing sustainable agriculture, and the Isan Wisdom group has produced some successful cases.

\subsection{Functioning of Sustainable Agriculture}

What are the "functionings" of sustainable agriculture? First, farmers can reduce production costs by practising sustainable agriculture. When they are practicing modern agriculture, they need to purchase chemical fertilisers, herbicides, and insecticides. By implementing sustainable agriculture which limits the use of agricultural chemicals, 
they can cut down on their production costs. Interviews were conducted on 46 households in NP village, and 34 out of the 46 are practising sustainable agriculture. Table 4 shows rice production costs per one rai in NP village from 2004 to 2007.

Table 4. Rice production costs per 1 Rai in NP village (2004-2007)

\begin{tabular}{|l|c|}
\hline Chemical fertilisers & B464 \\
\hline Agricultural labour & B188 \\
\hline Herbicides, insecticides & B 14 \\
\hline Other miscellaneous items & B 30 \\
\hline Total & B695 \\
\hline
\end{tabular}

The farmers of NP village were paying $\$ 464$ for chemical fertilisers, $\$ 188$ for agricultural labour, $\$ 14$ for herbicides and insecticides, and $\$ 30$ for other miscellaneous items. Thus, $67 \%$ of the total rice production cost was for chemical fertilisers. The community groups promoting sustainable agriculture are producing organic fertilisers and distributing them to the members. Farmers can access organic fertilisers at a very low cost. Therefore, farmers of NP village could significantly reduce their rice production costs by introducing organic fertilisers.

Especially since 2008, prices of chemical fertilisers have risen precipitously. There was a sharp rise in raw material prices in the international market. As a result, the rice production costs have been increasing. Reducing the use of expensive chemical fertilisers may be an urgent issue for most farmers. In NP village, many farmers complained about the soaring prices of chemical fertilisers. The soaring chemical fertiliser prices may have pushed the farmers to introduce sustainable agriculture.

Second, farmers can procure resources for living at low costs all year round. Sustainable agriculture, especially integrated agriculture, requires building a farm pond in the field and growing multiple crops. Generally, the pond has to be large enough to store rainwater for use in the dry season. Farmers can grow a variety of vegetables and fruits to eat and sell by using the water reserve.

This is the case with Mr Suchart. He is growing sticky rice from April to November. Before he implemented sustainable agriculture, he went to Bangkok as a migrant worker in the dry season. However, after he implemented sustainable agriculture, he is growing some vegetables in the dry season. He is growing corn and beans from December to March by using the water in the pond he built in his field. He is utilising his limited field more efficiently and trying to procure resources to live on without having to do migrant work.

His annual income is only $\mathrm{B} 30,000$ which is equal to the village average, but it is much lower than the regional average. There are limitations of sustainable agriculture. When sustainable agriculture is assessed in terms of an income generation source, the contribution may be very limited. Although sustainable agriculture is not profitable, it could contribute to the sustainability of the rural livelihoods of small-scale farmers.

By implementing sustainable agriculture, villagers could cope with the ageing of the rural population. The ageing population has been increasing in northeast Thailand as with other regions. The proportion of the ageing population (defined as aged 65 and 
over) is relatively high, $12.2 \%$ in Khon Kaen Province in 2003. Furthermore, there is a tendency to have a higher ageing index in rural areas compared with urban areas according to NSO. Some research indicates that rural, northeast Thailand is ageing rapidly. One reason is that young people tend to move away from rural areas towards urban areas seeking better jobs or higher education. Another reason is that it is physically, culturally, and psychologically difficult for older adults to move out and find non-agricultural employment in urban areas. Therefore, older adults need to procure resources for their livelihood in the rural areas. Sustainable agriculture would help them to procure the resources they need.

In NP village, 26 out of 46 households have been staying in the village without relying on migrant work. Sixteen out of the 26 households don't have a young labour force (aged below 50). Eleven out of the 16 households are implementing sustainable agriculture. This study suggests that sustainable agriculture could cut down production costs and help stabilise the livelihood of small-scale farmers and older adults in rural, northeast Thailand.

\section{Discussion and Conclusions}

In $\mathrm{BC}$ village located in a suburban area, most villagers are engaged in both farming and non-farming activities. They have various opportunities to earn a cash income. For the villagers of $\mathrm{BC}$ village, it is not difficult to keep staying in the village throughout the year.

In contrast, in NP village located in a remote area, the vast majority of villagers are engaged in farming activities. No one commutes to the city of Khon Kaen. To stay on in the village during the dry season, they need to sustain their lives depending on their scarce farmland, water resources, and the lack of a cash income. Under these restrictive conditions, sustainable agriculture could be one option to procure resources for living. By practising sustainable agriculture, they can cut down production costs and living expenses. Moreover, they can keep staying on in the village even in the dry season.

Some limitations of sustainable agriculture have been pointed out. Generally, it is difficult for small-scale farmers to introduce this farming method because of scarce resources. However, some small-scale farmers can introduce sustainable agriculture. In NP village, a community group named Isan Wisdom designed the One Rai Project which is applicable for small-scale farmers. Twenty-two out of 46 households are practising sustainable agriculture on their limited farmland. They can grow produce to market and for their own table all year round, even in the dry season. Unless they practise sustainable agriculture, they cannot keep staying on in the village during the dry season. In that sense, sustainable agriculture could generate a viable choice for them. 


\section{References}

CIIFAD, 1999. Alternatives to Conventional Modern Agriculture for Meeting World Needs in the Next Century. Report of a conference on sustainable agriculture: evaluation of new paradigms and old practices (Ithaca: Cornell International Institute for Food, Agriculture and Development) p. 26-30

Kitahara, A., 2002. Hendou no Tounan Asia Aokishoten.

NESDB, 1997. Rural Development Natural Resources and Environmental Conservation and Prosperity Decentralization during the eighth plan (1997-2001). (Bangkok: NESDB)

NESDB, 2004. Kaanpramen kaanpattana sakkayapab Lae kunnapab chivit kasettakorn kong kaanpattana kaankaset baeb yangyuen (The Evaluation of the Capacity Development and Life Quality of Sustainable Agriculture). (Bangkok: NESDB)

NESDB, 2013. Gross Regional and Provincial Product Chain Volume Measure 2013 Edition, (Bangkok: NESDB)

NSO, 2003. The 2003 Agricultural Census Khon Kaen (CD-R). (Bangkok: NSO)

NSO, 2007. Statistical Yearbook Thailand 2007 (Special Edition) (CD-R). (Bangkok: NSO)

NSO, 2012. Household Socio-Economic Survey Northeastern Region. (Bangkok: NSO)

NSO, 2013. Agricultural Census of Northeastern Region (CD-R). (Bangkok: NSO)

Rambo, A. T., 2017. The Agrarian Transformation in Northeastern Thailand: A Review of Recent Research Southeast Asian Studies 6 (2) p 211-245

Sen, A., 1999. Development as Freedom. (Oxford: Oxford University Press)

Takeuchi, T., 2014. Touhoku Thai no Nouson kougyou (Rural Small Industry in Northeastern Thailand) Ritsumeikan Annual Review of International Studies 26 (4) p 593-615

Thanwa, J., 2001. Sustainable Agricultural Systems for Small-scale Farmers in Thailand: Implications for the Environment. (Taipei: Food and Fertilizer Technology Center)

Watanabe, K., 2017. Improvement in Rain-fed Rice Production during an Era of Rapid National Economic Growth: A Case Study of a Village in Northeast Thailand Southeast Asian Studies 6 (2) p 293-306. 